\title{
EFFECTS OF POULTRY LITTER CONCENTRATION AND SUBSTRATE SOURCE ON THE DEVELOPMENT OF Mangifera indica L. 'COQUINHO'
}

\author{
CONCENTRAÇÕES DE CAMA DE FRANGO E FONTES DE SUBSTRATOS NA \\ PRODUÇÃO DE PORTA-ENXERTOS DE Mangifera indica L. 'COQUINHO'
}

\section{Givago COUTINHO ${ }^{1}$; Berildo de MELO $^{2}$; Paulo Roberto Bernardes ALVES ${ }^{2}$; Quintiliano Siqueira Schroden NOMELINI ${ }^{3}$; Fernando Cezar JULIATTI ${ }^{2}$}

1. Professor, Doutor, Centro Universitário de Goiatuba, Campus de Goiatuba, Goiatuba, GO, Brasil. 2. Professor, Doutor, Universidade Federal de Uberlândia, Instituto de Ciências Agrárias, Campus de Uberlândia, Uberlândia, MG, Brasil; 3. Professor, Doutor, Universidade Federal de Uberlândia, Faculdade de Matemática, Campus de Uberlândia, Uberlândia, MG, Brasil. givago_agro@hotmail.com

\begin{abstract}
We conducted two experiments to evaluate the growth of mango (Mangifera indica L., $\mathrm{CV}$ Coquinho) rootstock in different substrates and determine the optimal concentration of poultry litter amendments to the soil in combination with seeds with or without an endocarp endocarp. The following factors were studied in the first experiment: substrate source: soil, soil + poultry litter (at $25 \%$ ) and a commercial substrate. In the second experiment, we studied poultry litter amendments at $0 \%$ (just soil), $20 \%$ and $40 \%$. Both experiments evaluated the presence or absence of the seed endocarp on: plant height, stem diameter (tree base) and leaf count at 60,75,90,105 and 120 days after sowing (DAS). After conducting field measurements, we evaluated fresh shoot weight (FW) and then dry shoot weight (DW) after drying at $65^{\circ} \mathrm{C}$. No significant differences among the substrate sources or concentrations of poultry litter amendments relative to rootstock development. However, rootstock produced from seeds with no endocarps outperformed all other treatments.
\end{abstract}

KEYWORDS: Endocarp. Mangifera indica L.. Seeds. Soil.

\section{INTRODUCTION}

Mango (Mangifera indica L.) is one of the most commonly cultivated and consumed fruits in the world. Nevertheless, research is lacking on the profitable expansion of this crop. Simão et al. (1997), mentions that despite the global importance of the mango relative to other tropical fruits, there is still little information on the cultivation of this crop and especially regarding the use of rootstock, which is consequently limited.

When propagating rootstock, it is recommended to rigorously select productive parent plants, varieties or cultivars of commercial interest that are free from pests and diseases. Currently, mango rootstock is used according to regional need, adaptation and availability. In the southeast of Brazil, the most common cultivars are Coração de boi, Espada, Coquinho, Jasmin, Rosinha, Ubá and Sapatinho. The Indian cultivars Malika and Amraali are used when smaller plants and denser stands are desired (RUFINI et al., 2007).

Coquinho is a traditional Brazilian cultivar whose fruit weighs from 90 to 120 grams, has firm flesh and short fibers and is used for rootstock (LORENZI, 2006). Mango seeds have inherent morphological and physiological characteristics that may inhibit propagation, such as recalcitrance and an endocarp that hinders germination.

Consequently, several physical and chemical seed treatments are recommended to minimize germination problems, increase germination rates and improve the uniformity of emergence (SANTOS et al., 2009).

Therefore, we evaluated substrate sources and concentrations of poultry litter amendments combined with seeds with or without an endocarp in order to determine which combination produced the most vigorous rootstock development in the Coquinho mango.

\section{MATERIAL AND METHODS}

\section{Experiment setup}

The experiment was set up in May, 2013 at the Agua Limpa Experimental Farm (highway MG$455, \mathrm{Km} \mathrm{18)}$ of the Federal University of Uberlandia, Uberlandia, MG, Brazil. We used a randomized block design (RBD) in split plots (three substrate sources, with and without seed endocarp), for a total of six treatments with six replicates for each substrate source and three substrates consisting of soil with different concentrations of poultry litter, with and without seed endocarp, with six treatments and five replications for the poultry litter 
concentrations. The experimental plots in both experiments consisted of five plants each with one rootstock per container.
Figures 1 and 2 show variations in the temperature and relative humidity of the air during the experiment.

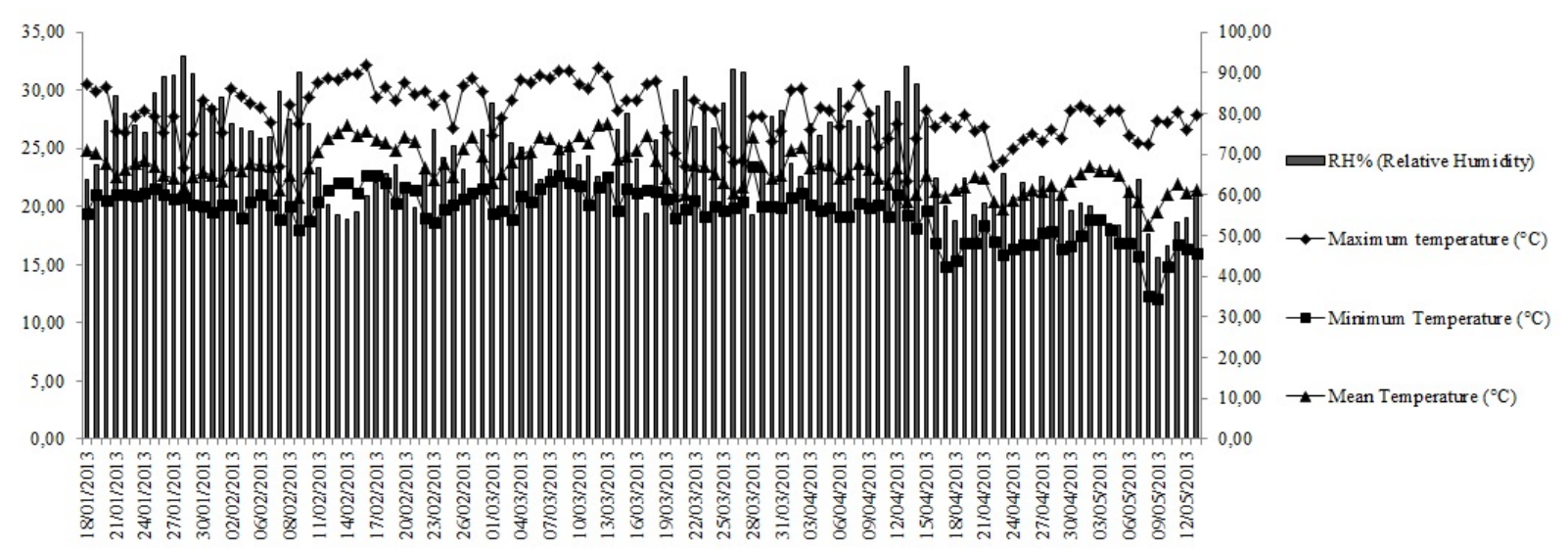

Figure 1. Relative humidity $(\%)$, minimum temperature $\left({ }^{\circ} \mathrm{C}\right)$, maximum temperature $\left({ }^{\circ} \mathrm{C}\right)$, mean temperature $\left({ }^{\circ} \mathrm{C}\right)$ during the experiment. Source: Laboratory of Climatology and Water Resources (Laboratório de Climatologia e Recursos Hidricos), UFU. Uberlandia, Minas Gerais, 2014.

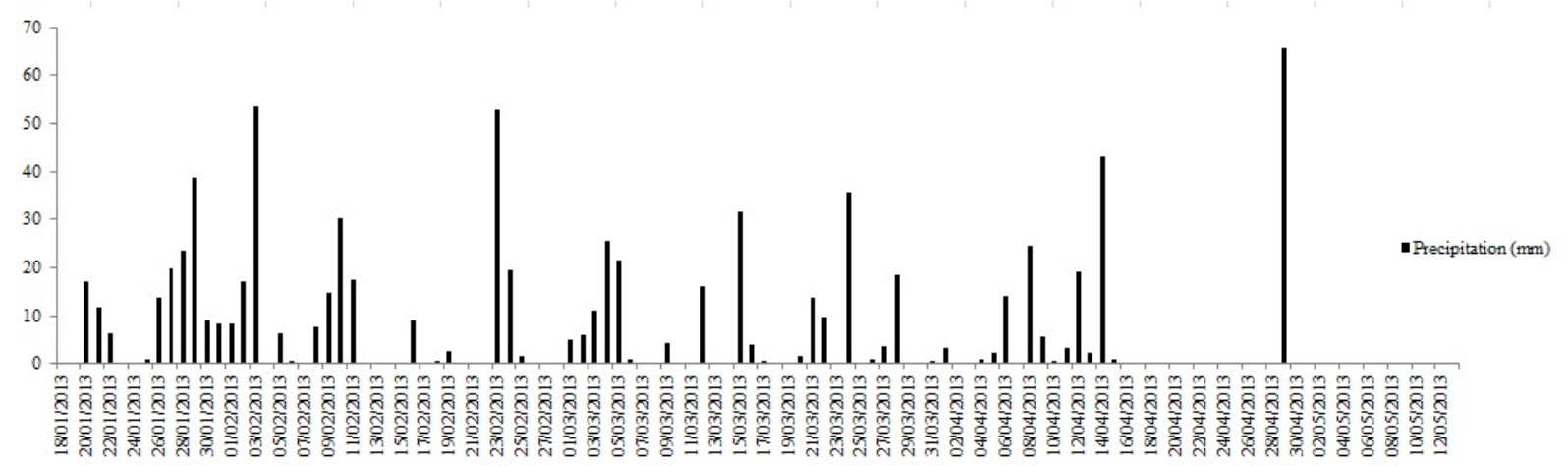

Figure 2. Rainfall $(\mathrm{mm})$ at the Agua Limpa Farm during the experiment. Source: Laboratory of Climatology and Water Resources (Laboratório de Climatologia e Recursos Hidricos), UFU. Uberlandia, Minas Gerais, 2014.

\section{Sample preparation}

The treatments are referred to by the following abbreviations (Table 1).

Table 1. Treatments used and the experiment and their respective abbreviations.

\section{Treatments}

Soil + Seed without endocarp

Commercial substrate + Seed without endocarp

Soil with $25 \%$ poultry litter + Seed without endocarp

Soil + Seed with endocarp

Commercial substrate + Seed with endocarp

Soil with $25 \%$ poultry litter + Seed with endocarp

Soil + Seed without endocarp

Soil with $20 \%$ poultry litter + Seed without endocarp

Soil with $40 \%$ poultry litter + Seed without endocarp

Soil + Seed with endocarp

Soil with $20 \%$ poultry litter + Seed with endocarp

Soil with $40 \%$ poultry litter + Seed with endocarp
Abbreviations TS

SS

CS

TE

SE

$\mathrm{CE}$

TS

VS

QS

TE

VE

QE 
The treatments in the first part of the study were: soil without addition of organic material, a commercial substrate (composed of a principal raw material, pine bark, coconut fiber binders, vermiculite, rice hulls and nutrients, $\mathrm{pH} 5.7$, humidity $25 \%$ ) and soil with the addition of $25 \%$ poultry litter. In the second part of the experiment, the treatments consisted of: different rates of poultry litter $\left(0 \%, 20 \%\right.$ and $\left.40 \% \mathrm{vv}^{-1}\right)$ added to the substrate and rootstock produced form seeds with or without endocarps. Each experimental unit consisted of five plants with one plant per container.

The seeds were obtained from mature washed fruit from the orchard at the Agua Limpa Experimental Farm of the Federal University of Uberlandia. The endocarps were left on one group of seeds and removed from the rest. The seeds were sown in plastic containers $(28 \mathrm{~cm} \times 25 \mathrm{~cm})$ with one seed per container. Irrigation was performed by sprayer and occurred three times per week for two hours, except on days with natural rainfall. The maximum rainfall during the period was approximately $65 \mathrm{~mm}$. Weeds were eliminated manually.

The soil used as the substrate was acquired from deep soil horizons located near the nursery Phosphorus was added to the soil and mixtures of soil and poultry litter via one liter of superphosphate $\left(17 \% \mathrm{P}_{2} \mathrm{O}_{5}\right.$ and $\left.3 \% \mathrm{~N}\right)$. The $\mathrm{pH}$ of the substrates was corrected with one liter of dolomitic limestone (100\% Effective Calcium Carbonate Equivalent and 96\% total Calcium Carbonate Equivalent) for each cubic meter $\left(\mathrm{m}^{3}\right)$ of substrate.

Chemical analysis of the macro and micronutrient content of the soil and poultry litter were carried out at the Laboratory of Soil Analysis (Laboratório de Análise de Solos) at the Federal University of Uberlandia in Uberlandia, MG, Brazil (Tables 2, 3 and 4).

Table 2. Chemical analysis of the soil. Uberlandia, MG, 2014.

\begin{tabular}{|c|c|c|c|c|c|c|c|c|c|c|c|}
\hline Soil & $\overline{\text { pH }}$ & $\overline{\mathbf{P}}$ & $\mathbf{K}$ & ${ }_{2+} \mathrm{Ca}$ & ${ }_{2+} \mathrm{Mg}$ & ${ }_{3+}$ Al & $\mathrm{Al}^{\mathrm{H}+}$ & $\overline{\text { SB }}$ & $\mathrm{C}^{\mathrm{CE}}$ & $\mathbf{V}$ & $\begin{array}{l}\text { Organic } \\
\text { matter }\end{array}$ \\
\hline Unit & $\mathrm{H}_{2} \mathrm{O}$ & & & - & - & $\operatorname{mol}_{\mathrm{c}} \mathrm{dl}$ & 3 & & & $\%$ & $\begin{array}{l}\text { Dag } \\
\text { kg }^{-1}\end{array}$ \\
\hline & 5.6 & 9. & 39 & 0.6 & 0.3 & $0^{0 .}$ & 1.20 & 1.00 & $0^{1.0}$ & 46 & 0.6 \\
\hline
\end{tabular}

Table 3. Macronutrients in poultry litter. Uberlandia, MG, 2014.

\begin{tabular}{|c|c|c|c|c|c|c|c|c|}
\hline $\begin{array}{l}\text { Poultry } \\
\text { litter }\end{array}$ & $\overline{p H}$ & Density & $\overline{\mathbf{N}}$ & $\overline{\mathbf{P}}$ & $\mathbf{K}$ & $\mathrm{Ca}^{2+}$ & $\mathrm{Mg}^{2+}$ & $\mathbf{S}$ \\
\hline Unit & $\begin{array}{l}\mathrm{CaCl}_{2} \\
0.01 \mathrm{M}^{2}\end{array}$ & $\mathrm{~g} \mathrm{~cm}^{-3}$ & & 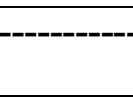 & $----\%$ & --------- & & \\
\hline & 7.40 & 0.55 & $\begin{array}{ll} & 1.9 \\
2 & \end{array}$ & $5^{3.5}$ & $9^{2.2}$ & 18.05 & 0.75 & 0.4 \\
\hline
\end{tabular}

Table 4. Micronutrients in poultry litter. Uberlandia, MG, 2014.

\begin{tabular}{cccccccc}
\hline $\begin{array}{c}\text { Poultry } \\
\text { litter }\end{array}$ & $\mathbf{p H}$ & $\mathbf{B}$ & $\mathbf{C u}$ & $\mathbf{F e}$ & Mn & Zn & Na \\
\hline Unit & $\begin{array}{c}\mathbf{C a C l}_{2} \\
\mathbf{0 . 0 1} \mathbf{M}\end{array}$ & $\mathbf{m g ~ \mathbf { ~ g g } ^ { - 1 }}$ & & & & & \\
\cline { 2 - 7 } & 7.40 & 23 & 82 & 1310 & 596 & 67 & 2582 \\
\hline
\end{tabular}

\section{Execution of the experiment}

White flies (Bemisia sp., Hemiptera Aleyrodidae) were controlled at 60 days after sowing (DAS) using thiamethoxan $(75 \% \mathrm{~m} / \mathrm{m}$, where the first $(\mathrm{m})$ is the mass of the solute and the second (m) is the solution) at $1 \mathrm{~g} \mathrm{~L}^{-1}$. At $70 \mathrm{DAS}$, thiophanate methyl $(70 \% \mathrm{w} / \mathrm{v})$ at $2 \mathrm{~g} \mathrm{~L}^{-1}$ and acephate $(75 \% \mathrm{~m} / \mathrm{m})$ at $1 \mathrm{~g} \mathrm{~L}-1$ were applied to control anthracnose on the leaves of the rootstock. At the end of the evaluations (120 DAS), the shoots of the rootstock were collected and weighed on a precision scale to obtain the fresh weight $(\mathrm{g})$. Next, the shoots were dried at $65^{\circ} \mathrm{C}$ for 24 hours, until reaching a constant weight, and then 
Effects of poultry...

weighed again to obtain the dry weight (STAHL et al. 2013).

\section{Statistical analysis}

Statistical analysis was chosen that was appropriate for our temporal split-plot experiment (i.e. sample plots subdivided in time). Thus, the data were submitted to analysis of variance by $F$ test and the averages were compared by the Tukey test with $\alpha=0.05$ using the SISVAR software package (FERREIRA, 2011).

Height values estimated by the following model were transformed to the units of the original variable using $(($ height $\mathrm{T} *(-0.2))+1) \wedge(1 /(-$ $0.2)$ ). This procedure was carried out in Excel with strict observance of parentheses. The means in table 5 and those estimated for height, where the letter
COUTINHO, G. et al.

was transformed, were tranformed to the original Heights using the box-cox transformation:

alturaT $=\frac{\text { altura }^{\lambda}-1}{\lambda} \rightarrow$ altura $=(\text { alturaT } * \lambda+1)^{\frac{1}{\lambda}}$

where $\lambda$ is estimated by the maximum likelihood method so that the transformed data approaches a normal distribution.

\section{RESULTS AND DISCUSSION}

\section{Height (cm), diameter (cm) and leaf count}

Independent analysis showed that for height $(\mathrm{cm})$ and diameter $(\mathrm{cm})$, there was no interaction between substrate source and time. Height was thus analyzed by an independent model (Figure 3 ).

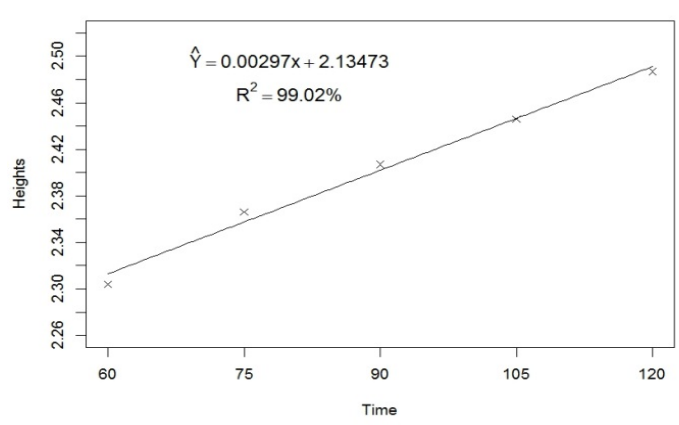

Figure 3. Rootstock heights of the mango cultivar 'Coquinho' over time, regardless of substrate source. Uberlandia, MG, 2014.

The height of rootstock from seeds without endocarps developed faster. However, a significant difference in this characteristic was not observed relative to the different substrates used. Stem diameter $(\mathrm{cm})$ at the base of the rootstock did not differ among substrate type throughout the period of the study. This suggests that height development occurs more quickly, while stem diameter increases at later stages in development (Table 5).

Table 5. Height $(\mathrm{cm})$ and diameter $(\mathrm{cm})$ of the mango rootstock with different substrate sources, and seeds with and without endocarp.

\begin{tabular}{lcc}
\hline Sources & Height $\mathbf{( c m})^{\mathbf{1}}$ & Diameter $\mathbf{( c m )}$ \\
\hline TE & $25.313 \mathrm{~b}$ & $0.556 \mathrm{a}$ \\
SE & $24.835 \mathrm{~b}$ & $0.582 \mathrm{a}$ \\
CE & $20.235 \mathrm{c}$ & $0.512 \mathrm{a}$ \\
TS & $30.147 \mathrm{ab}$ & $0.586 \mathrm{a}$ \\
CS & $28.422 \mathrm{ab}$ & $0.589 \mathrm{a}$ \\
SS & $31.368 \mathrm{a}$ & $0.587 \mathrm{a}$ \\
\hline CV $\%$ & 5.30 & 21.22 \\
\hline LSD & - & 0.096 \\
\hline & $\mathrm{D}=0.07 ; \chi^{2}=5.65 ;$ & $\mathrm{D}=0.04 ; \chi^{2}=3.64 ;$ \\
\hline
\end{tabular}

* Means followed by distinct letters within a column differ by the Tukey test at the 0.05 level of significance; $C V$ : coefficient of variation; $L S D$ : least significant difference; $D, \chi^{2}, D W, F$ : respectively, statistics for the Kolmogorov-Smirnov tests with Lilliefors correction, Bartlett, Durbin-Watson and Tukey additivity; Values in bold indicate normally distributed and independent residuals, homogeneous variances and additive block effects; ${ }^{1}$ Analysis of the data transformed by Box-Cox ( $\left.\lambda=-0.2\right)$, but means are in the original units. 
Similarly, Santos et al. (2009) studied Manguita and Espada cultivars and found that the mean height of plants grown from seeds without endocarps were significantly taller than those grown from seeds with endocarps. The authors state that these differences probably occurred because the plants in the treatments without endocarps emerged earlier than those with endocarps.

Figure 4 shows that the diameter growth curve of rootstock had no interaction when examined independently from the substrate source.

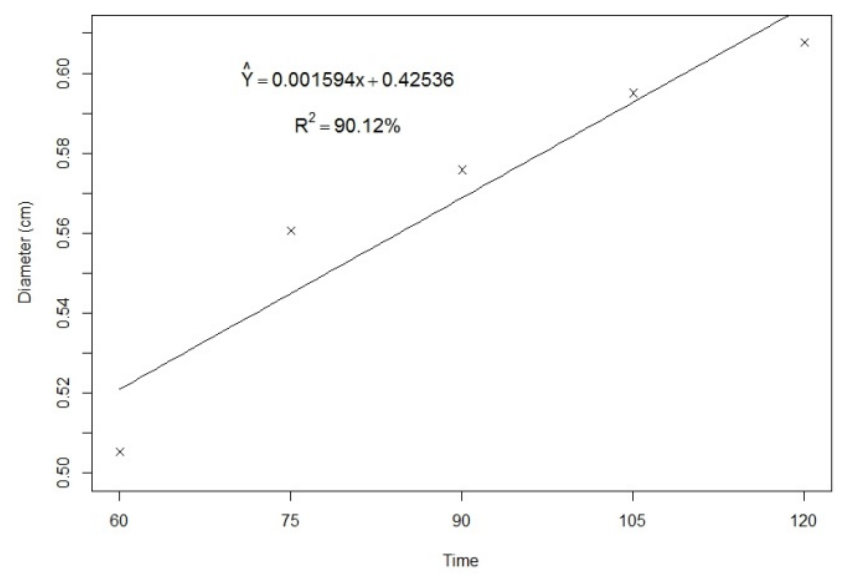

Figure 4. Rootstock diameter of the mango cultivar 'Coquinho' over time, independent of substrate source. Uberlandia, MG, 2014.

For plant height $(\mathrm{cm})$, there was a significant interaction between poultry litter concentrations in combination with the seed in the presence or absence of the endocarp and rootstock development time (Table 6); however, there was no difference between the poultry litter concentrations, such that, during the evaluation time, all poultry litter concentrations contributed the same to rootstock development in this cultivar.

Table 2. Rootstock height $(\mathrm{cm})$ with different concentrations of poultry litter added to the substrate, for seeds with and without endocarps. Uberlandia, MG, 2014.

\begin{tabular}{lccccc}
\hline $\begin{array}{c}\text { Poultry litter } \\
\text { concentration }\end{array}$ & $\mathbf{6 0}$ & $\mathbf{7 5}$ & $\mathbf{9 0}$ & $\mathbf{1 0 5}$ & $\mathbf{1 2 0}$ \\
\cline { 2 - 6 } & $16.36 \mathrm{~b}$ & $18.51 \mathrm{~b}$ & $20.02 \mathrm{c}$ & $21.41 \mathrm{c}$ & $23.05 \mathrm{~d}$ \\
$\mathrm{TE}$ & $18.30 \mathrm{ab}$ & $20.80 \mathrm{~b}$ & $22.78 \mathrm{bc}$ & $25.36 \mathrm{bc}$ & $28.28 \mathrm{~cd}$ \\
$\mathrm{VE}$ & $18.56 \mathrm{ab}$ & $20.88 \mathrm{~b}$ & $22.72 \mathrm{bc}$ & $24.80 \mathrm{bc}$ & $29.67 \mathrm{bcd}$ \\
$\mathrm{QE}$ & $23.82 \mathrm{ab}$ & $27.92 \mathrm{ab}$ & $30.06 \mathrm{ab}$ & $31.24 \mathrm{ab}$ & $35.58 \mathrm{abc}$ \\
$\mathrm{TS}$ & $24.78 \mathrm{ab}$ & $27.64 \mathrm{ab}$ & $29.68 \mathrm{ab}$ & $32.76 \mathrm{ab}$ & $38.18 \mathrm{ab}$ \\
$\mathrm{QS}$ & $26.37 \mathrm{a}$ & $30.80 \mathrm{a}$ & $32.82 \mathrm{a}$ & $36.16 \mathrm{a}$ & $43.83^{\mathrm{a}}$ \\
$\mathrm{VS}$ & $\mathrm{C}$ & & \\
\hline $\mathrm{CV}$ & &
\end{tabular}

Adding organic matter to substrates is recommended and confirms the results of Lima et al. (2006) who found that organic material is frequently added to substrates used in the production of rootstocks because it adds nutrients and improves the physical characteristics of the media.
The growth curves for height $(\mathrm{cm})$ show that the highest values refer to substrates containing seeds without endocarps (Figure 5). Faster growth is important in the production of rootstock because it shortens production times and therefore saves time, space and resources within the nursery. 


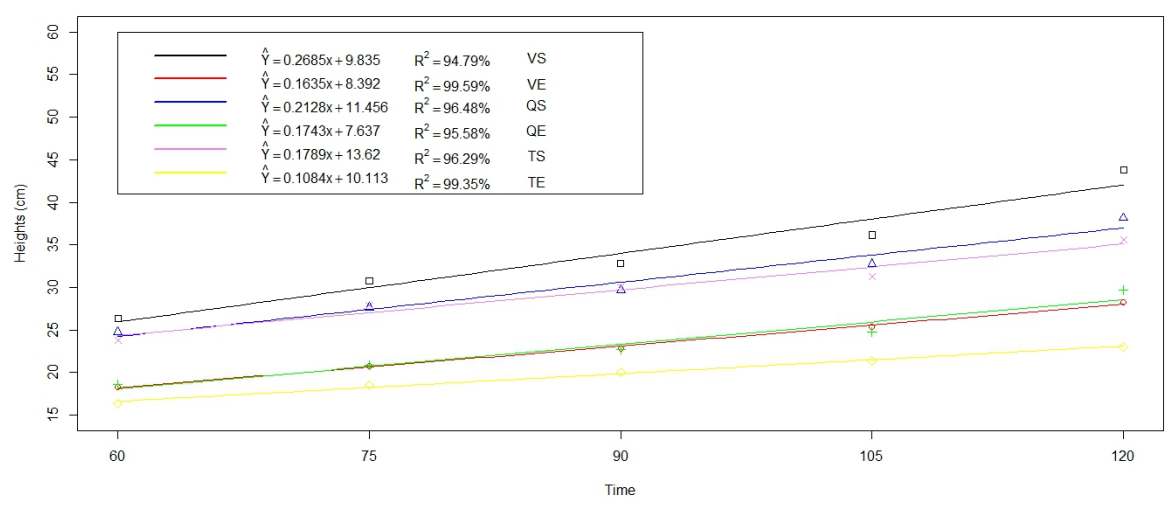

Figure 5. Plant height $(\mathrm{cm})$ over time as a function of the concentration of poultry litter added to the substrate. Uberlandia, MG, 2014.

Stem diameter $(\mathrm{cm})$ behaved the same way as height in that there was significant interaction among poultry litter concentrations and rootstock development time; however, there were no significant differences among the various poultry litter concentrations (Table 7).
Figure 6 shows the growth curves for the diameter $(\mathrm{cm})$ of the root stock, relative to time as a function of poultry litter concentration.

Leaf count (Table 8) did not differ among the substrate sources. Differences in the results were probably due to seed variability.

Table 3. Rootstock diameter $(\mathrm{cm})$ with different poultry litter concentrations for seeds with and without endocarps. Uberlandia, MG, 2014.

\begin{tabular}{cccccc}
\hline $\begin{array}{c}\text { Poultry litter } \\
\text { concentration }\end{array}$ & $\mathbf{6 0}$ & $\mathbf{7 5}$ & $\mathbf{9 0}$ & $\mathbf{1 0 5}$ & $\mathbf{1 2 0}$ \\
\hline TE & $0.455 \mathrm{a}$ & $0.479 \mathrm{a}$ & $0.491 \mathrm{~b}$ & $0.501 \mathrm{~b}$ & $0.555 \mathrm{~b}$ \\
$\mathrm{VE}$ & $0.432 \mathrm{a}$ & $0.496 \mathrm{a}$ & $0.512 \mathrm{~b}$ & $0.544 \mathrm{~b}$ & $0.568 \mathrm{~b}$ \\
$\mathrm{QE}$ & $0.440 \mathrm{a}$ & $0.476 \mathrm{a}$ & $0.512 \mathrm{~b}$ & $0.524 \mathrm{~b}$ & $0.584 \mathrm{~b}$ \\
$\mathrm{TS}$ & $0.520 \mathrm{a}$ & $0.600 \mathrm{a}$ & $0.632 \mathrm{ab}$ & $0.608 \mathrm{ab}$ & $0.667 \mathrm{ab}$ \\
$\mathrm{QS}$ & $0.520 \mathrm{a}$ & $0.580 \mathrm{a}$ & $0.628 \mathrm{ab}$ & $0.628 \mathrm{ab}$ & $0.708 \mathrm{ab}$ \\
$\mathrm{VS}$ & $0.577 \mathrm{a}$ & $0.636 \mathrm{a}$ & $0.676 \mathrm{a}$ & $0.713 \mathrm{a}$ & $0.768 \mathrm{a}$ \\
\hline $\mathrm{CV}_{\mathrm{Concentration}}=26.86 \% ; \mathrm{CV}_{\text {Time }}=5.20 \% \mathrm{LSD}=0.161$ & &
\end{tabular}

$\mathrm{CV}_{\text {Concentration }}=26.86 \% ; \mathrm{CV}_{\text {Time }}=5.20 \% ; \mathrm{LSD}=0.161$

$\mathrm{D}=0.07 ; \chi^{2}=3.87 ; \mathrm{DW}=2.47 ; \mathrm{F}=3.27$

* Means followed by distinct letters within a column differ by the Tukey test at the 0.05 level of significance; $C V$ : coefficient of variation; $L S D$ : least significant difference; $D, \chi^{2}, D W, F$ : respectively, statistics for the Kolmogorov-Smirnov tests with Lilliefors correction, Bartlett, Durbin-Watson and Tukey additivity; Values in bold indicate normally distributed and independent residuals, homogeneous variances and additive block effects.

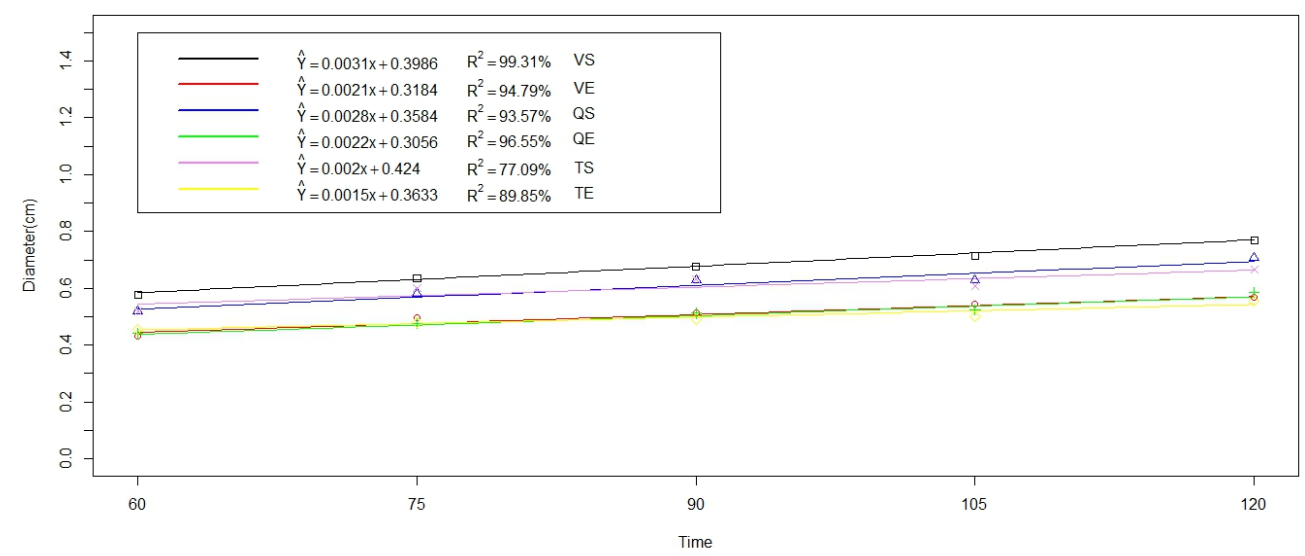

Figure 6. Rootstock diameter $(\mathrm{cm})$ over time as a function of poultry litter concentration in the substrate. Uberlandia-MG, 2014. 
Table 8. Leaf count for the mango rootstock produced in different substrate sources relative to seeds with and without endocarps. Uberlandia, MG, 2014.

\begin{tabular}{|c|c|c|c|c|c|}
\hline \multirow{2}{*}{ Sources } & \multicolumn{5}{|c|}{ Time } \\
\hline & 60 & 75 & 90 & 105 & 120 \\
\hline TE & $8.103 \mathrm{a}$ & $\begin{array}{l}10.050 \\
\mathrm{ab}\end{array}$ & $10.400 \mathrm{bc}$ & $12.608 \mathrm{bcd}$ & $12.925 \mathrm{bc}$ \\
\hline $\mathrm{SE}$ & $7.650 \mathrm{a}$ & $9.200 \mathrm{~b}$ & $10.067 \mathrm{c}$ & $11.533 \mathrm{dc}$ & $12.167 \mathrm{c}$ \\
\hline $\mathrm{CE}$ & $7.742 \mathrm{a}$ & $9.167 \mathrm{~b}$ & $9.983 \mathrm{c}$ & $11.233 \mathrm{~d}$ & $12.633 \mathrm{bc}$ \\
\hline TS & $10.125 \mathrm{a}$ & $\begin{array}{l}12.300 \\
\mathrm{ab}\end{array}$ & $14.367 \mathrm{a}$ & $15.808 \mathrm{ab}$ & $16.192 \mathrm{ab}$ \\
\hline $\mathrm{CS}$ & $9.983 \mathrm{a}$ & $\begin{array}{l}11.867 \\
\mathrm{ab}\end{array}$ & $12.833 \mathrm{abc}$ & $14.967 \mathrm{abc}$ & $16.733 \mathrm{a}$ \\
\hline $\mathrm{SS}$ & $10.267 \mathrm{a}$ & $13.333 \mathrm{a}$ & $13.900 \mathrm{ab}$ & $16.333 \mathrm{a}$ & $18.233 \mathrm{a}$ \\
\hline \multicolumn{6}{|c|}{$\mathrm{CV}_{\text {Source }}=30.83 \% ; \mathrm{CV}_{\text {Time }}=7.83 \% ; \mathrm{LSD}=3.691$} \\
\hline \multicolumn{6}{|c|}{$\mathrm{D}=0.07 ; \chi^{2}=9.70 ; \mathrm{DW}=2.28 ; \mathrm{F}=4.04$} \\
\hline
\end{tabular}

Franzon et al. (2010) states that seed-grown plants intended for fruit production are mainly used to obtain rootstock and in general vary widely, even when produced from the same parent plant. Therefore, the use of these plants should be avoided in commercial orchards.
The growth curves of rootstock leaf count relative to substrate source show that leaf count increases more quickly for seeds without endocarps (Figure 7). In this case, it is more likely that the plant will reach the ideal stage for grafting more quickly.

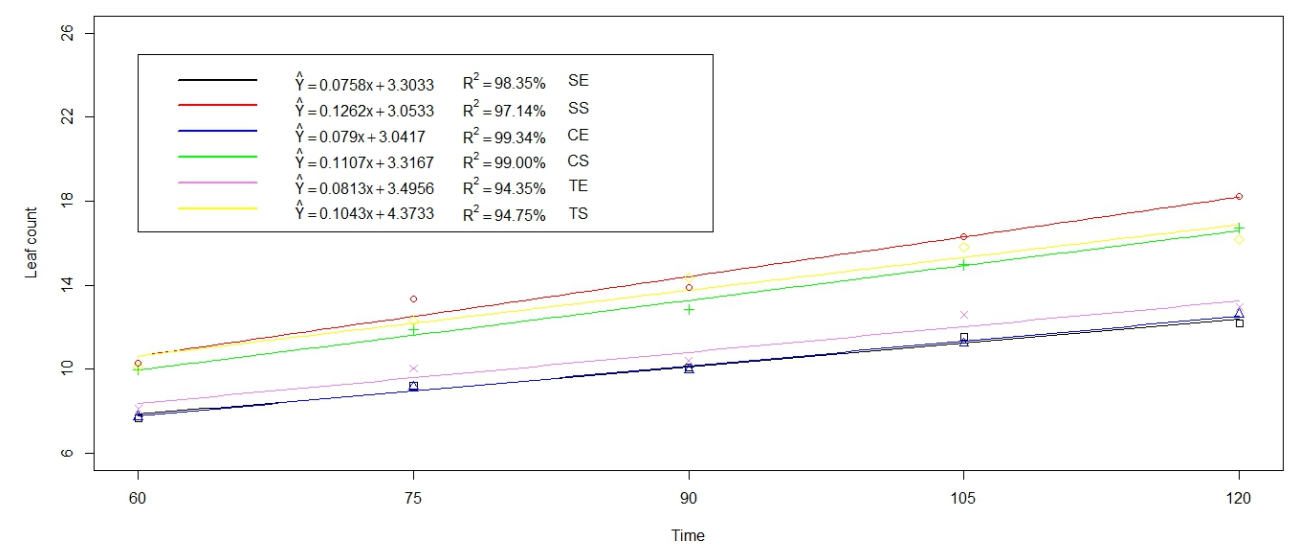

Figure 7. Rootstock leaf count over time and in relation to substrate source. Uberlandia, MG, 2014.

Removal of the endocarp may allow faster germination and consequently may allow the plant to reach the ideal stage for grafting more quickly. This may occur because the fruit is a drupe with a single seed that is deep within and tightly adhered to the fruit. The process begins with the development of the ovary wall or pericarp that thickens and differentiates into layers - the exocarp (outer layer), mesocarp (middle layer) and the endocarp (inner layer). These layers are distinct in fleshy fruits such as the mango (RAVEN et al., 2001).

The endocarp produces a type of physical dormancy that is caused by the impermeability of the seed/fruit layers that wholly or partly restrict water diffusion to the embryo (KERBAUY, 2008), which complicates and delays germination.

Soilless substrates are important for highquality rootstock production because they limit problems resulting from insects and diseases that may be present in the soil.

Several authors have mentioned the importance of substrate choice and preparation in the production of fruit seedlings. Sirin et al. (2010), studied growth substrates and fig plant (Ficus carica L) production and pointed out that pest attack, disease and soil depletion are significant problems 
in producing young fig plants in a greenhouse, especially when soil is used as a substrate. The authors go on to suggest that soilless substrates could be useful alternatives to soil for producing healthy, high-quality young plants.
Table 9 shows that while the different poultry litter concentrations did not lead to differences in leaf count, relevant results were achieved with seeds without endocarps.

Table 9. Leaf count in mango rootstock produced with different poultry litter concentrations and from seeds with or without endocarps. Uberlandia, MG, 2014.

\begin{tabular}{lccccc}
\hline $\begin{array}{l}\text { Poultry litter } \\
\text { concentration }\end{array}$ & $\mathbf{6 0}$ & $\mathbf{7 5}$ & $\mathbf{9 0}$ & $\mathbf{1 0 5}$ & $\mathbf{1 2 0}$ \\
\cline { 2 - 6 } $\mathrm{TE}$ & $6.66 \mathrm{a}$ & $7.83 \mathrm{c}$ & $9.89 \mathrm{~b}$ & $10.99 \mathrm{c}$ & $12.00 \mathrm{c}$ \\
$\mathrm{VE}$ & $7.72 \mathrm{a}$ & $10.16 \mathrm{bc}$ & $10.96 \mathrm{~b}$ & $13.48 \mathrm{bc}$ & $15.28 \mathrm{bc}$ \\
$\mathrm{QE}$ & $7.52 \mathrm{a}$ & $10.88 \mathrm{abc}$ & $10.64 \mathrm{~b}$ & $12.04 \mathrm{bc}$ & $15.36 \mathrm{bc}$ \\
$\mathrm{TS}$ & $10.84 \mathrm{a}$ & $13.96 \mathrm{ab}$ & $14.92 \mathrm{ab}$ & $15.32 \mathrm{abc}$ & $18.26 \mathrm{ab}$ \\
$\mathrm{QS}$ & $10.64 \mathrm{a}$ & $13.72 \mathrm{abc}$ & $14.68 \mathrm{ab}$ & $17.20 \mathrm{ab}$ & $20.92 \mathrm{ab}$ \\
$\mathrm{VS}$ & $12.29 \mathrm{a}$ & $16.75 \mathrm{a}$ & $17.87 \mathrm{a}$ & $19.75 \mathrm{a}$ & $23.71 \mathrm{a}$ \\
\hline $\mathrm{CV}$ & & & \\
\hline $\mathrm{D}=0.07 ; \chi^{2}=6.43 ; \mathrm{DW}=2.58 ; \mathrm{F}=0.002$ &
\end{tabular}

* Means followed by distinct letters within a column differ by the Tukey test at the 0.05 level of significance; $C V$ : coefficient of variation; $L S D$ : least significant difference; $D, \chi^{2}, D W, F$ : respectively, statistics for the Kolmogorov-Smirnov tests with Lilliefors correction, Bartlett, Durbin-Watson and Tukey additivity; Values in bold indicate normally distributed and independent residuals, homogeneous variances and additive block effects.

Figure 8 shows that leaf counts were higher in rootstock produced from seeds without endocarps than from seeds with endocarps.

\section{Fresh weight (g) and dry weight $(\mathrm{g})$}

Table 10 shows the accumulation of fresh $(\mathrm{g})$ and dry weight $(\mathrm{g})$ of the rootstocks. It can be seen that there were no significant differences among the results relative to substrate source.

The fresh weight of the rootstock shoots was superior when grown from seeds without endocarps than from seeds with endocarps, but otherwise did not differ significantly (Tukey, 0.05). Therefore, removal of the endocarp is important in producing rootstock of this mango cultivar.

Dry weight (measured after drying for 24 hours at $65{ }^{\circ} \mathrm{C}$ ) of rootstock grown from seeds without endocarps was significantly higher than that from treatments where the endocarp was left on the seeds.

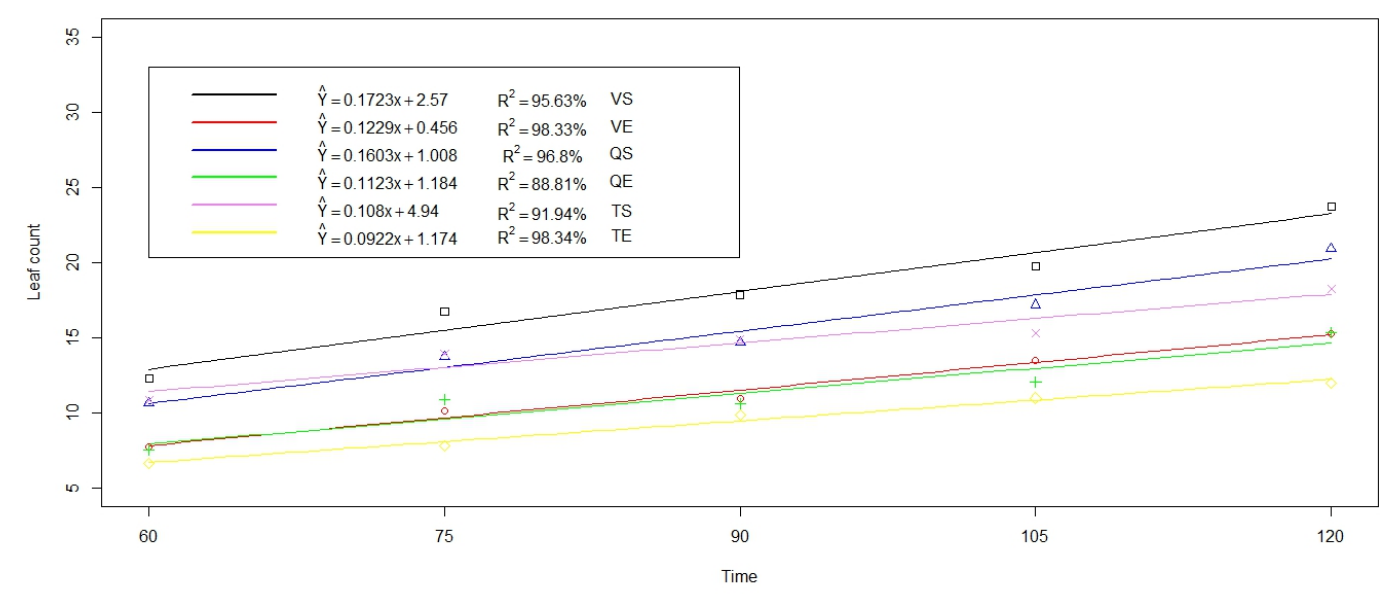

Figure 8. Leaf count over time as a function of poultry litter concentration in the substrate. Uberlandia, MG, 2014. 
Table 10. Fresh weight $(\mathrm{g})$ and dry weight $(\mathrm{g})$ of rootstock shoots grown in different substrate sources and from seeds with and without endocarps. Uberlandia, MG, 2014.

\begin{tabular}{lcc}
\hline Sources & Fresh weight (g) & Dry weight (g) \\
\hline TE & $14.925 \mathrm{ab}$ & $5.222 \mathrm{abc}$ \\
SE & $11.883 \mathrm{ab}$ & $3.787 \mathrm{bc}$ \\
CE & $9.425 \mathrm{~b}$ & $3.256 \mathrm{c}$ \\
TS & $18.633 \mathrm{a}$ & $7.437 \mathrm{a}$ \\
CS & $19.333 \mathrm{a}$ & $6.978 \mathrm{a}$ \\
SS & $19.017 \mathrm{a}$ & $6.094 \mathrm{ab}$ \\
\hline DMS & 8.129 & 2.759 \\
\hline CV \% & 29.40 & 28.39 \\
\hline & $\mathrm{W}=0.98 ; \chi^{2}=12.40 ;$ & $\mathrm{W}=0.99 ; \chi^{2}=11.92 ;$ \\
\hline
\end{tabular}

* Means followed by distinct letters within a column differ by the Tukey test at the 0.05 level of significance; $C V$ : coefficient of variation; $L S D$ : least significant difference; $D, \chi^{2}, D W, F$ : respectively, statistics for the Kolmogorov-Smirnov tests with Lilliefors correction, Bartlett, Durbin-Watson and Tukey additivity; Values in bold indicate normally distributed and independent residuals, homogeneous variances and additive block effects.

Pio et al., 2004 states that alternative substrates should not be overlooked for seedling production. The authors emphasize that in addition to various commercial substrates, nursery growers must have other substrate alternatives and especially ones that use easily acquired components such as riverbank soils, sand and cow manure that promote rootstock growth and quality and reduce costs

There were no significant differences in fresh weight (FW) and dry weight (DW) relative to the different concentrations of poultry litter added to the substrate (Table 11).

Table 11. Fresh weight $(\mathrm{g})$ and dry weight $(\mathrm{g})$ of rootstock shoots grown in different concentrations of poultry litter and from seeds with and without endocarps. Uberlandia, MG, 2014.

\begin{tabular}{ccc}
\hline Poultry litter concentrations & Fresh weight & Dry weight \\
\hline TE & $10.01 \mathrm{c}$ & $4.62 \mathrm{c}$ \\
VE & $14.40 \mathrm{bc}$ & $5.77 \mathrm{bc}$ \\
QE & $15.08 \mathrm{bc}$ & $6.07 \mathrm{bc}$ \\
TS & $19.91 \mathrm{abc}$ & $8.71 \mathrm{abc}$ \\
QS & $25.18 \mathrm{ab}$ & $10.12 \mathrm{ab}$ \\
VS & $31.35 \mathrm{a}$ & $11.97 \mathrm{a}$ \\
\hline DMS & 12.21 & 4.90 \\
\hline CV $\%$ & 31.77 & 31.29 \\
\hline & $\mathrm{W}=0.99 ; \chi^{2}=4.76 ;$ & $\mathrm{W}=0.99 ; \chi^{2}=5.96 ;$ \\
\hline
\end{tabular}

* Means followed by distinct letters within a column differ by the Tukey test at the 0.05 level of significance; $C V$ : coefficient of variation; $L S D$ : least significant difference; $D, \chi^{2}, D W, F$ : respectively, statistics for the Kolmogorov-Smirnov tests with Lilliefors correction, Bartlett, Durbin-Watson and Tukey additivity; Values in bold indicate normally distributed and independent residuals, homogeneous variances and additive block effects.

Our results show the importance of using animal waste from agriculture, which is both environmentally friendly and economically viable, as confirmed by several other studies. Trazzi et al. (2013) studied the application of organic and animal waste in the production teak seedlings and found that adding bovine manure, poultry litter and quail manure to substrates increased the total nutrient content of the substrates and the nutrients available for plant nutrition.

Different results were found by Araújo et al. (2015) who studied papaya seedlings (cv. Tainung01) and found that bovine manure added to the substrate produced the greatest growth gains (e.g. growth and accumulation of biomass) compared to the other organic soil amendments studied (Bokashi ${ }^{\circledR}$, Ovine Manure, Bovine Manure, Bokashi + Bovine Manure (1:1) and Bokashi + Ovine Manure (1:1)).

\section{CONCLUSIONS}

Removing the endocarp from seeds led to better developed rootstock, regardless of substrate type, compared to rootstock produced from seeds with endocarps. 
Effects of poultry...

The presence of the seed endocarp yielded the poorest results among all the characteristics analyzed.

\section{ACKNOWLEDGEMENTS}

COUTINHO, G. et al.

The following Brazilian organizations are recognized for their support of research in the state of Minas Gerais and throughout Brazil: Fundação de Amparo à Pesquisa do estado de Minas Gerais (FAPEMIG) and the Conselho Nacional de Desenvolvimento Científico e Tecnológico (CNPq).

RESUMO: Com o intuito de avaliar o desenvolvimento de porta-enxertos de mangueira (Mangifera indica L.) 'Coquinho', em diferentes fontes de substratos e determinar a concentração ideal de cama de frango na adição ao solo em combinação com a semente na presença ou ausência do endocarpo, foram conduzidos dois experimentos. No primeiro, foram estudados os seguintes fatores: fonte de substrato empregada: solo, solo + cama de frango a $25 \%$ e substrato comercial. No segundo, estudou-se a adição de cama de frango ao solo nas seguintes proporções de $0 \%$ (apenas solo), $20 \%$ e $40 \%$. Ambos em relação à presença ou ausência do endocarpo na semente. As características avaliadas foram: altura de planta, diâmetro do caule na altura do colo e número de folhas e efetuadas aos 60, 75, 90, 105 e 120 dias após a semeadura (DAS). Ao término das mensurações de campo, procedeu-se a pesagem da parte aérea das plantas para obtenção da massa fresca (MF) e posteriormente sua secagem em estufa a $65^{\circ} \mathrm{C}$ para determinação da massa seca (MS). Os resultados mostraram não haver diferença significativa entre os substratos ou entre as concentrações de cama de frango. Entretanto, os porta-enxertos produzidos a partir de sementes sem a presença do endocarpo demonstraram maior desenvolvimento em relação aos demais com endocarpo.

PALAVRAS-CHAVE: Endocarpo. Mangifera indica L.. Sementes. Solo.

\section{REFERENCES}

ARAÚJO, E. B. G.; ALMEIDA, L. L. S.; FERNANDES, F.; SÁ, F. V. S.; NOBRE, R. G.; PAIVA, E. P.; MESQUITA, E. F.; PORTELA, J. C. Fontes e doses de matéria orgânica na produção de mudas de mamoeiro. Revista Agropecuária Técnica, v. 36, n. 1, p. 264-272, 2015.

FERREIRA, D. F. Sisvar: a computer statistical analysis system. Ciência e Agrotecnologia, Lavras, v. 35, n. 6, p. 1039-1042, 2011. https://doi.org/10.1590/S1413-70542011000600001

FRAZON, R. C.; CARPENEDO, S.; SILVA, J. C. S. Produção de mudas, principais técnicas utilizadas na produção de fruteiras. Planaltina: EMBRAPA Cerrados, 2010. (Documentos, n. 283).

KERBAUY, G. B. Fisiologia vegetal. 2. ed. Rio de Janeiro: Guanabara Koogan, 2008. p. 406.

LIMA, R. L. S. SEVERINO, L. S.; SILVA, M. I. L.; JERÔNIMO, J. F.; VALE, L. S. DO.; BELTRÃO, N. E. M. Substratos para produção de mudas de mamoneira compostos por misturas de cinco fontes de matéria orgânica. Ciência e Agrotecnologia, Lavras, v. 30, n. 3, p. 474-479, 2006. https://doi.org/10.1590/S141370542006000300013

LORENZI, H.; BACHER, L.; LACERDA, M.; SARTORI, S. Frutas Brasileiras e exóticas cultivadas: de consumo in natura. Nova Odessa: Instituto Plantarum de Estudos da Flora, 2006. 672 p.

PIO, R. GONTIJO, T. C. A.; CARRIJO, E. P.; RAMOS, J. D.; TOLEDO, M.; VISIOLI, E. L.; TOMASETTO, F. Efeito de diferentes substratos no crescimento de mudas de nespereira. Revista Brasileira de Agrociência, Pelotas, v.10, n. 3, p. 309-312, 2004.

RAVEN, P.H.; EVERT, R.F.; EICHHORN, S.E. Biologia vegetal. 6. ed. Rio de Janeiro: Guanabara Koogan, 2001. p. 491-523. 
PAULA JUNIOR, T.J.; VENZON, M. (Org.). 101 culturas: manual de tecnologias agrícolas. Belo Horizonte: Epamig, 2007. 800 p.

SANTOS, J. P.; SANTANA, C. V. S.; SILVA, M. A. S.; ROCHA, R. C. Emergência e taxa de poliembrionia em sementes de mangueira (Mangifera indica), cultivar Manguita e Espada, com e sem tegumento. Revista Verde, Mossoró, v.4, n.4, p. 49-53, 2009.

SIMÃO, S. Mangueira: influência do porta-enxerto e da copa na produção de frutas. Sciencia agrícola, Piracicaba, v. 54, n. 3, p 183-188, 1997. https://doi.org/10.1590/S0103-90161997000200012

SIRIN, U.; ERTAN, E.; ERTAN, B. Growth substrates and fig nursery tree production. Sciencia Agricola, Piracicaba, v.67, n.6, p.633-638, 2010. https://doi.org/10.1590/S0103-90162010000600003

STAHL, J.; ERNANI, P. R.; GATIBONI, L. C.; CHAVES, D. M.; NEVES, C. U. Produção de massa seca e eficiência nutricional de clones de Eucalyptus dunnii e Eucalyptus benthamii em função da adição de doses de fósforo ao solo. Ciência Florestal, Santa Maria, v. 23, n. 2, p. 287-295, 2013.

https://doi.org/10.5902/198050989275

TRAZZI, P. A.; CALDEIRA, M. V. W.; PASSOS, R. R.; GONÇALVES, E. O. Substratos de origem orgânica para produção de mudas de teca (Tectona grandis Linn. F.), Ciência Florestal, Santa Maria, v. 23, n. 3, p. 401409, 2013. https://doi.org/10.5902/1980509810551 